\title{
Relationships Between Egg Weight and Albumen Height in Quails and Investigating the Validity of the Presumptions that is in Commonly Used Quality Measurements Under Diverse Conditions
}

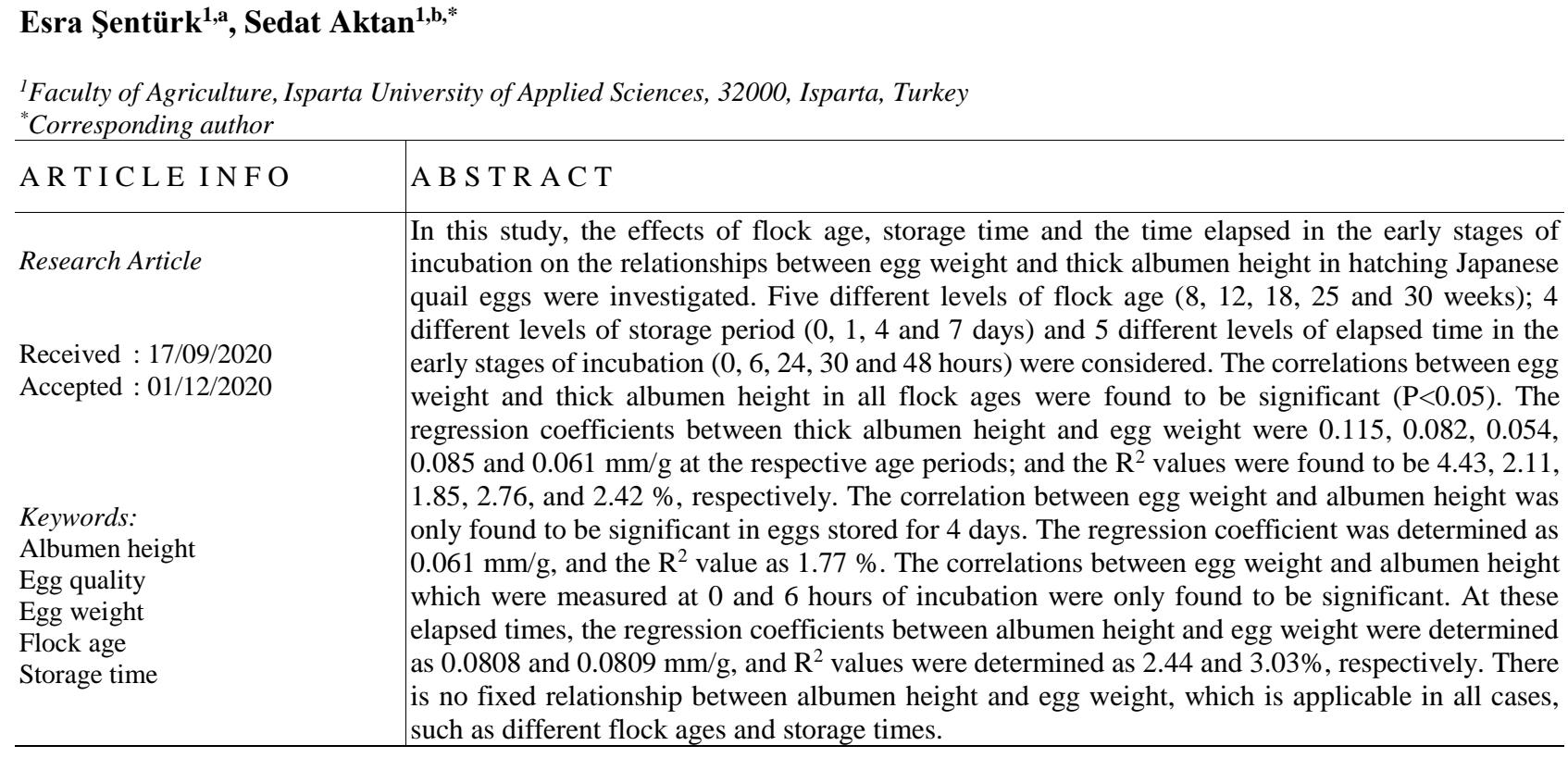

Tavukçuluk Araştırma Dergisi 17(2): 80-86, 2020

\section{Bıldırcınlarda Yumurta Ağırlığı ile Ak Yüksekliği Arasındaki İliş̧kiler ve Yaygın Kullanılan Kalite Özelliklerindeki Ön Kabullerin Çeşitli Koşullar Altındaki Geçerliliklerinin Araştırılması}

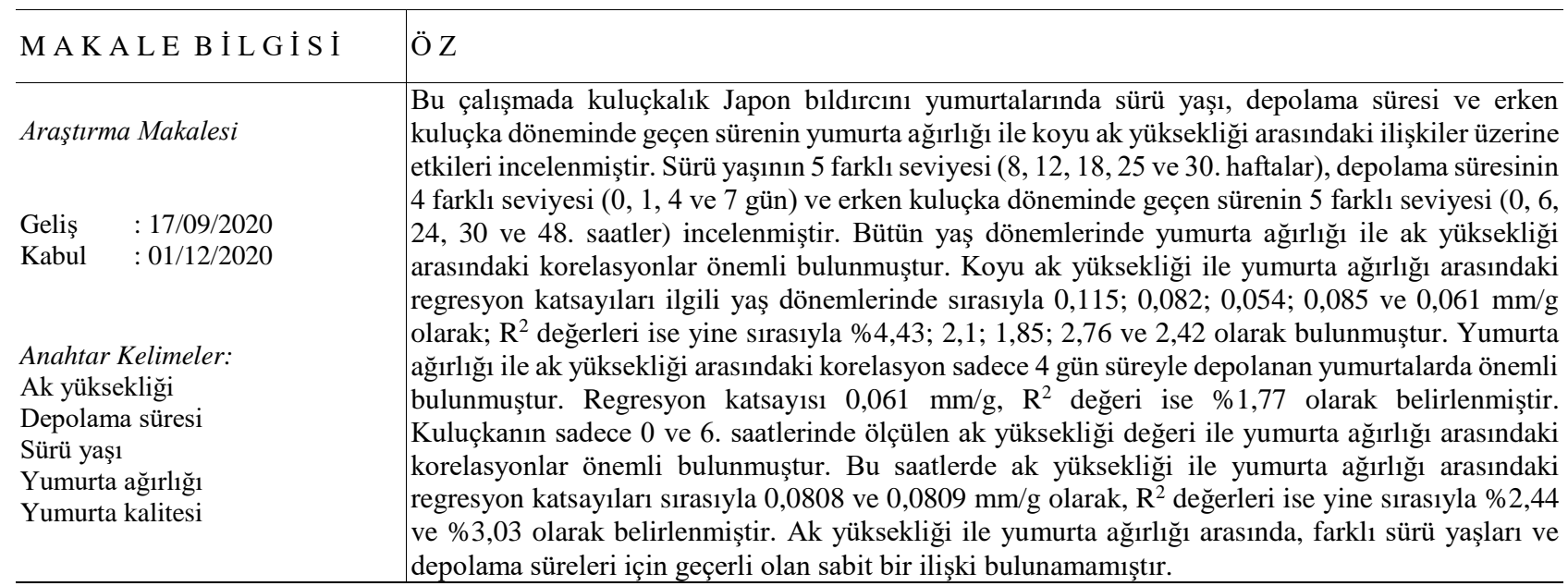




\section{Giriş}

Yumurta kalitesi gerek yemeklik gerekse kuluçkalık yumurtalar için önemli olup, ovipozisyon öncesi ve sonrası pek çok faktör, tüm kanatlı türlerinde iç ve dış kalite özelliklerini etkileyebilmektedir. Özellikle yumurta ağırlığı, kabuk kalitesi ve koyu ak kalitesi, tüm yumurta kalite özellikleri içerisinde bariz şekilde öne çıkmaktadır. Yemeklik yumurtalar kırıldığında koyu akın daha geniş alana yayılması, tüketiciler tarafından bayatlığa işaret eden bir gösterge olarak kabul edilmektedir. Elbette düzgün bir geometrik şekli olmayan alan ölçümü zordur. Bunun yerine ak yüksekliği, uzunluk ve genişliği, ak pH değeri gibi doğrudan ölçülebilen parametreler veya koyu aka ilişkin ölçümler ve yumurta ağırlığının kullanıldığı bazı formüller yardımıyla elde edilen ak indeksi, Haugh Unit (HU), Internal Quality Unit (IQU) gibi değerler de kullanılabilmektedir.

İlk defa Raymond Haugh tarafından geliştirilen HU eşitliği (Haugh, 1937), o tarihten günümüze kadar yaygın olarak kullanılmakta, diğer taraftan çok sayıda araştırıcı tarafından da uzun yıllardır eleştirilmektedir (Eisen ve ark., 1962; Williams, 1992). Eleştirilerin kökeninde, HU değerinin hesaplanmasında yumurta ağırlığında meydana gelen bir birimlik (g) değişmeye karşıllık, ak yüksekliğinde 0,05 birimlik $(\mathrm{mm})$ değişme meydana geldiği ön kabulünden hareketle, bu ön kabulün genelleştirilmesi ve her genotip, yaş ve depolama süresi için sabit bir regresyon katsayısı kullanımının hatalı olacağı yer almaktadır (Eisen ve ark., 1962; Silversides ve Villeneuve, 1994).

Ak yüksekliği üzerinde beslemeyle ilgili etmenlerin genellikle etkisiz olduğu; genotip, sürü yaşı, depolama süresi ve depolama koşullarının ak yüksekliği üzerinde etkili olduğu; hesaplanan regresyon katsayısı değerlerinin ise $-0,058$ ile $+0,102$ arasında değiştiği bildirilmiştir (Hill ve Hall, 1980; Silversides ve Scott, 2001). Bu çekincelerden hareketle, kimi araştırıcılar koyu ak yüksekliği değerlerinin herhangi bir düzeltme yapılmaksızın, doğrudan kullanılmasını önerirlerken, kimi araştırmacılar Japon bıldırcını gibi farklı türlere ait yumurtalar için HU hesaplamada kullanılan eşitlikten esinlenerek IQU gibi farklı formüller geliştirmişler; kimi araştırmacılar da $\mathrm{HU}$ yerine, iç kalitenin tespitinde $\mathrm{pH}$ gibi genotip ve yaşın etkide bulunmadığ 1 parametrelerin kullanılmasının daha isabetli olacağını öne sürmüşlerdir (Silversides ve Villeneuve, 1994; Silversides ve Scott, 2001; Kondaiah ve ark., 1983). Taze bildırcin yumurtalarında yapılan çalışmalarda, IQU değerinin HU değerine göre daha isabetli sonuç verdiği ve tespit edilen IQU değerinin ortalama 62,12 olduğu, IQU değeriyle diğer iç kalite ölçüm değerleri arasında önemli düzeyde pozitif korelasyon olduğu bulgusuna ulaşılmıştır (Kondaiah ve ark., 1983; Imai, 1986).

Koyu ak yüksekliğinin işlevsel önemi açıklanmış bir konu olmasa da, depolama süresinin uzamasiyla koyu ak yüksekliğinin logaritmik olarak azalmasına bağlı olarak yumurta tazeliğinin ölçülmesinde kullanılabilir. Koyu ak proteinlerinden "ovomucin" toplam yumurta ak1 proteinlerinin \%3-5'lik kısmını oluşturmakta, koyu aka akışmazlık sağlayarak, ak yüksekliğini önemli ölçüde belirlemekte ve hızla denatüre olabilme niteliğindedir. Ortam amonyak düzeyi gibi hidrojen iyon $(\mathrm{H}+)$ aktivitesini etkileyen ortam koşullarına oldukça duyarlı olan taze yumurta akı, bu koşullar altında hızla sıvılaşarak ak yüksekliğinin azalmasına neden olmaktadır. Aslında bu süreçler, kuluçka sırasında embriyonun ihtiyaçlarının giderilmesi için kolaylaştırıcı niteliktedir (Silversides ve Scott, 2001; Toussant ve Latshaw, 1999; Lechevalier ve ark., 2011). Bıldırcın yumurtalarında ak yüksekliğinin 3,6$3,9 \mathrm{~mm}$ arasında değiştiği (Vogt, 1965) 73 ve 101 günlük yaştaki bıldırcınlarda yumurta ağırlıklarının sırasıyla 9,66 ve $10,47 \mathrm{~g}$, HU değerinin yine sirasiyla 85,53 ve 82,75 olduğu (Uluocak ve ark., 1995) 20 haftalık yaştaki bıldırcınlarda yumurta ağırlığı, koyu ak yüksekliği ve HU değerlerinin sirasıyla $11,28 \mathrm{~g}, 3,8 \mathrm{~mm}$ ve 85,73 olduğu (Kul ve Şeker, 2004) ilk 10 yumurta ağırlığının 10,14$10,88 \mathrm{~g}$ arasında, pik verim periyodunun başlangıcı olan 10 haftalık yaşta 11,33-11,76 g olduğu (Alarslan, 2006) Yağmur bildırcınlarında (C. coromandelica) ortalama yumurta ağırlığının 10,96-11,67 g, HU değerinin ise 69,7175,44 olduğu (Zynudheen ve ark., 2008) farklı bildırcın hatlarında ortalama yumurta ağırlıklarının 10,8-13,4 g olduğu (Karabağ ve ark., 2010) 21 haftalık bildırcınlarda koyu ak yüksekliği ve HU değerinin sırasıyla $3,64 \mathrm{~mm}$ ve 85,35 olduğu (Özçelik, 2002) bildirilmiştir.

Yumurta ak1 kalite değerlerinin depolama süresi uzadıkça kısa süre içinde kötüleştiği, aynı şekilde sürü yaşı ilerledikçe ak kalitesinde de düşüş gözlendiği bildirilmiştir (Jacob ve ark., 1998).

Yine bıldırcınlarda 10,15 ve 20 haftalık yaşlarda yumurta ağırlığı 11,99-12,26 g arasında; ak yüksekliği 4,01-4,422 mm arasında; ak yüksekliğinin logaritmasının 0,6-0,641 arasında; HU değerinin 86,18-88,72 ve IQU değerinin 52,68-58,42 arasında; ak pH değerinin ise 9,359,46 arasında değiştiği, ak yüksekliği/kalitesi ile ilgili belirlenen bütün bu parametrelerin sürü yaşı ve depolama süresinden etkilendiği, ancak ak pH'sı bakımından gözlenen bütün farklılıkların diğer parametrelerle ortaya konamadı $\breve{g}$, her ne kadar HU veya IQU koyu ak kalitesinin belirlenmesinde yaygın olarak kullanılsa da özellikle 9-11 $\mathrm{g}$ aralığı dışındaki yumurtalarda sıkıntılar yaşanabildiği; ak kalite özelliklerinin herhangi bir düzeltmeye tabi tutulmadan kullanılmasının daha doğru olduğu; kullanılması halinde ise öncesinde yumurta ağırlığı ile ak yüksekliği arasındaki ilişkilerin kontrol edilmesi gerektiği bildirilmiştir (Aktan, 2011a). Benzer durumun farklı genotipteki tavuk yumurtalarında da geçerli olduğu, kahverengi yumurtacı iki hibrit genotipte ak yüksekliği ile yumurta ağırlığı arasındaki regresyon katsayısının 0,02 $0,059 \mathrm{~mm} / \mathrm{g}$ olduğu, bu nedenle $\mathrm{HU}$ denkleminin geliştirilmesinde kullanılan $0,05 \mathrm{~mm} / \mathrm{g}$ lık ön şartın her durumda geçerli olmayacağı, $\mathrm{R}^{2}$ değerlerinin ise \%7,5-21,1 arasında değiştiği ifade edilmiştir (Aktan, 2011b).

Japon bıldırcını yumurtalarıyla yapılan bir başka çalışmada ise, parametrik testlerin uygulanamayacağ koşullarda Theil regresyon yardımıyla, yumurta ağılığ ile koyu ak yüksekliği arasındaki ilişki araştırılmış, özellikle çok az sayıdaki örnek genişliklerinde Theil regresyonun, doğrusal regresyonla benzer sonuçlar verdiği; farklı örnek genişlikleri için regresyon katsayıları içinde minimum değerin $0,098 \mathrm{~mm} / \mathrm{g}$ olduğu ifade edilmiştir (Koskan ve ark., 2016).

$\mathrm{Bu}$ çalışmada, Japon bıldırcınlarında (C. coturnix japonica) farklı yaş dönemlerinde elde edilen kuluçkalık 
yumurtalarda, farklı depolama süreleri ve kuluçkanın ilk döneminin farklı saatlerinde koyu ak yüksekliği ile yumurta ağırlığı arasındaki ilişkilerin ne ölçüde değiştiğinin belirlenmesi amaçlanmıştır.

\section{Materyal ve Yöntem}

Aynı gün kuluçkadan çıkan ve üç haftalık oluncaya kadar etlik civciv başlangıç yemi (\%23 HP, $3025 \mathrm{kcal} / \mathrm{kg}$ $\mathrm{ME})$, daha sonra yumurtacı piliç büyütme yemi (\%18 HP, $2950 \mathrm{kcal} / \mathrm{kg} \mathrm{ME}$ ) ve eşeysel olgunlukla birlikte kafes yumurta yemiyle (\%17 HP, $2750 \mathrm{kcal} / \mathrm{kg} \mathrm{ME}$ ) beslenen; yumurtlama dönemi boyunca bireysel kafeslerde, 1:1 cinsiyet oranında ve $16 \mathrm{~A}: 8 \mathrm{~K}$ aydınlatma programı altında tutulan toplam 270 bildircin, deneme materyali olan kuluçkalık yumurtaların elde edilmesinde kullanılmıştır.

Yumurtalar, bu sürüden $8,12,18,25$ ve 30 haftalık yaş dönemlerinde rastgele toplanmıştır. Yumurtalar her yaş döneminde günde en az üç kez toplanarak numaralandırılmış ve 0,01 grama duyarlı teraziyle tartılmış; 0 (kontrol), 1, 4 ve 7 gün süreyle $18^{\circ} \mathrm{C}$ ve $\% 60$ nem içeren koşullarda depolanmıştır. Belirtilen yaş dönemlerinde, farklı sürelerle depolanan yumurtalar, kuluçka makinesine rastgele yerleştirilmişler ve kuluçkanın 0, 6, 24, 30 ve 48. saatlerinde her alt gruptan en az 10 adet olacak şekilde yine rastgele seçilen yumurtalar tartılarak, cam bir yüzey üzerine kırılmış ve koyu ak yükseklikleri elektronik bir mikrometreyle belirlenmiştir. Kuluçkanın 0. saati kuluçkada geçen süre olarak değil, doğrudan depolama süresinin etkisini görmek için faktör seviyesi olarak dâhil edilmiştir.

Özetle, koyu ak yüksekliği ile yumurta ağırlığ1 arasındaki ilişkiler üzerine sürü yaşı faktörünün beş farklı seviyesi, depolama süresi faktörünün dört faklı seviyesi ve kuluçkada geçen süre faktörünün beş farklı seviyesi faktöriyel düzende ele alınmıştır. Verilerin istatistiki analizi için Statistica yazılımı kullanılmıştır. Veriler arasında hesaplanan korelasyon katsayılarının karşılaştırılmasında Fisher'in Z transformasyonu kullanılmıştır (Papoulis, 1990).

\section{Bulgular ve Tartışma}

Araştırmanın kapsamı geniş olduğundan, çalışmamızın sürü yaşı ve depolama süresinin koyu ak özellikleri üzerine etkisi ile kuluçka sonuçları üzerine etkisine ilişkin sonuçlarına bu makalede yer verilmemiştir. Yumurta ağırlığı ile koyu ak yüksekliği arasındaki ilişkileri incelemek açısından öncelikle ele alınan yaş dönemleri, kuluçkalık yumurta depolama süreleri ve kuluçkanın farklı saatlerinde bu iki değişken arasında hesaplanan fenotipik korelasyon katsayıları Çizelge 1'de verilmişstir.

Çizelge 1'de de görüldüğü üzere ele alınan tüm sürü yaşı dönemlerinde bu iki değişken arasındaki korelasyon katsayılarının istatistiki olarak önemli düzeyde olduğu gözlenmiştir. Bu korelasyon katsayıları kendi aralarında ikișerli olarak karşılaștırıldıklarında, aralarındaki farklılıkların istatistiki olarak önemli düzeyde olmadığı belirlenmiştir. Benzer bir çalışmada 10,15 ve 20 haftalık bıldırcınlardan elde edilen yumurtalarda, yumurta ağırlığ ile ak yüksekliği arasındaki korelasyon katsayıları elde ettiğimiz değerlere yakın, ancak istatistiki olarak önemsiz bulunmuştur (Aktan, 2011a).
Çizelge 1. Yumurta ağırlığı ile ak yüksekliği arasındaki korelasyon katsayıları $\left(\mathrm{r}_{\mathrm{xy}}\right)$

Table 1. Correlation coefficients beetween egg weight and albumen height $\left(r_{x y}\right)$

\begin{tabular}{c|rcc}
\hline \multicolumn{4}{c}{ Varyasyon kaynağ 1} \\
\hline Yaş (hafta) & $\mathrm{N}$ & $\mathrm{r}_{\mathrm{xy}}$ & $\mathrm{P}$ \\
8 & 235 & 0.211 & $<0.01$ \\
12 & 245 & 0.145 & $<0.05$ \\
18 & 235 & 0.136 & $<0.05$ \\
25 & 249 & 0.166 & $<0.01$ \\
30 & 242 & 0.155 & $<0.05$ \\
\hline \multicolumn{2}{c}{ Depo (gün) } & & \\
\hline 0 & 292 & 0.114 & 0.051 (ÖD) \\
1 & 300 & 0.108 & 0.062 (ÖD) \\
4 & 302 & 0.133 & $<0.05$ \\
7 & 312 & 0.036 & 0.528 (ÖD) \\
\hline Saat & & & \\
\hline 0 & 250 & 0.156 & $<0.05$ \\
6 & 237 & 0.174 & $<0.01$ \\
24 & 239 & -0.020 & 0.764 (ÖD) \\
30 & 243 & -0.072 & 0.264 (ÖD) \\
48 & 237 & 0.096 & 0.139 (ÖD) \\
\hline
\end{tabular}

ÖD: önemli değil

Bunun muhtemel nedeni, iki çalışma arasında beş kata yakın örnek genişliği farklılığı olmasıdır. Aşağıda da görüleceği üzere $\mathrm{R}^{2}$ değerleri oldukça düşük değerler almıştır. Her ne kadar depolama süresi bakımından, sadece 4 gün süreli depolanan yumurtalarda koyu ak yüksekliği ile yumurta ağırlığı arasındaki 0,133 düzeyindeki korelasyon katsayısı istatistiki olarak önemli bulunsa da $(\mathrm{P}<0,05), 0$ ve 1 gün süreyle depolanan yumurtalarda bu iki özellik arasındaki korelasyon katsayılarının da bu değere yakın olduğu (sırasıyla 0,114 ve 0,108 ) ve $P$ değerinin de 0,05 'e çok yakın olduğu fark edilecektir. Bilindiği üzere örnek genişliği çok az olduğunda, mesela sadece iki veri üzerinden hesaplama yapilırsa (iki noktadan her zaman bir doğru geçeceği için) korelasyon katsayısı 1 çıkarken, gereğinden çok fazla örnekle çalışıldığında ise korelasyon katsayısı düşük değer alsa bile istatistiki olarak önemli çıkabilmektedir.

Bilindiği üzere birer iç kalite parametresi olarak gerek HU ve gerekse IQU değerleri hesaplanırken bağımlı değişken (Y) olarak koyu ak yüksekliği, bağımsız değişken olarak da yumurta ağırlığ $(\mathrm{X})$ arasında sabit bir regresyon katsayısı olduğu varsayılmaktadır. Buna göre her yaş dönemi için bağımlı değişkenimiz koyu ak yüksekliği ve bağımsız değişkenimiz olan yumurta ağırlığı arasındaki doğrusal regresyon eğrileri hazırlanmıştır.

Koyu ak yüksekliği ile yumurta ağırlığı arasında 8,12 , 18,25 ve 30 haftalık yaş grupları için hazırlanan doğrusal regresyon eğrileri sırasıyla Şekil 1, Şekil 2, Şekil 3, Şekil 4 ve Şekil 5'de verilmiştir.

Şekillerden de anlaşılacağı gibi, ele alınan yaş gruplarında koyu ak yüksekliği ve yumurta ağırlığı arasında hesaplanan regresyon katsayılarının 8, 12, 18, 25 ve 30 haftalık yaş dönemlerinin hepsi için pozitif ve sirasiyla 0,$115 ; 0,082 ; 0,054 ; 0,085$ ve $0,061 \mathrm{~mm} / \mathrm{g}$ olduğu belirlenmiştir. Ayrıca yine bu yaş dönemlerinde koyu ak yüksekliği bakımından gözlenen varyasyonun sırasıly $\% 4,43 ; 2,11 ; 1,85 ; 2,76$ ve 2,42 gibi çok düşük oranlarda yumurta ağırlığına bağlı olduğu belirlenmiştir. 
8. hafta Ak Yüksekliği (mm)

$$
\begin{gathered}
\mathrm{y}=\mathrm{a}+\mathrm{bx} \\
\mathrm{r}^{2}=0.044324447 \\
\mathrm{a}=2.8065032 \\
\mathrm{~b}=0.1145815
\end{gathered}
$$

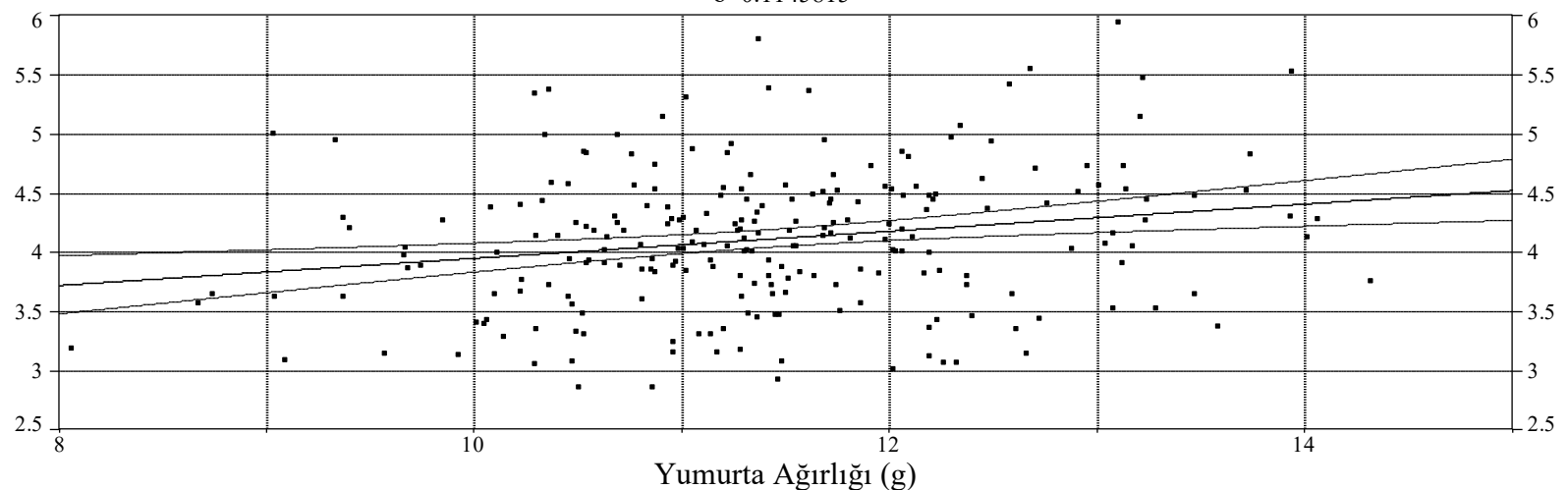

Şekil 1. Sekiz haftalık yaşta koyu ak yüksekliği ile yumurta ağırlığı arasındaki regresyon eğrisi Figure 1. Linear regression curve of thick albumen height on egg weight at eight weeks of age

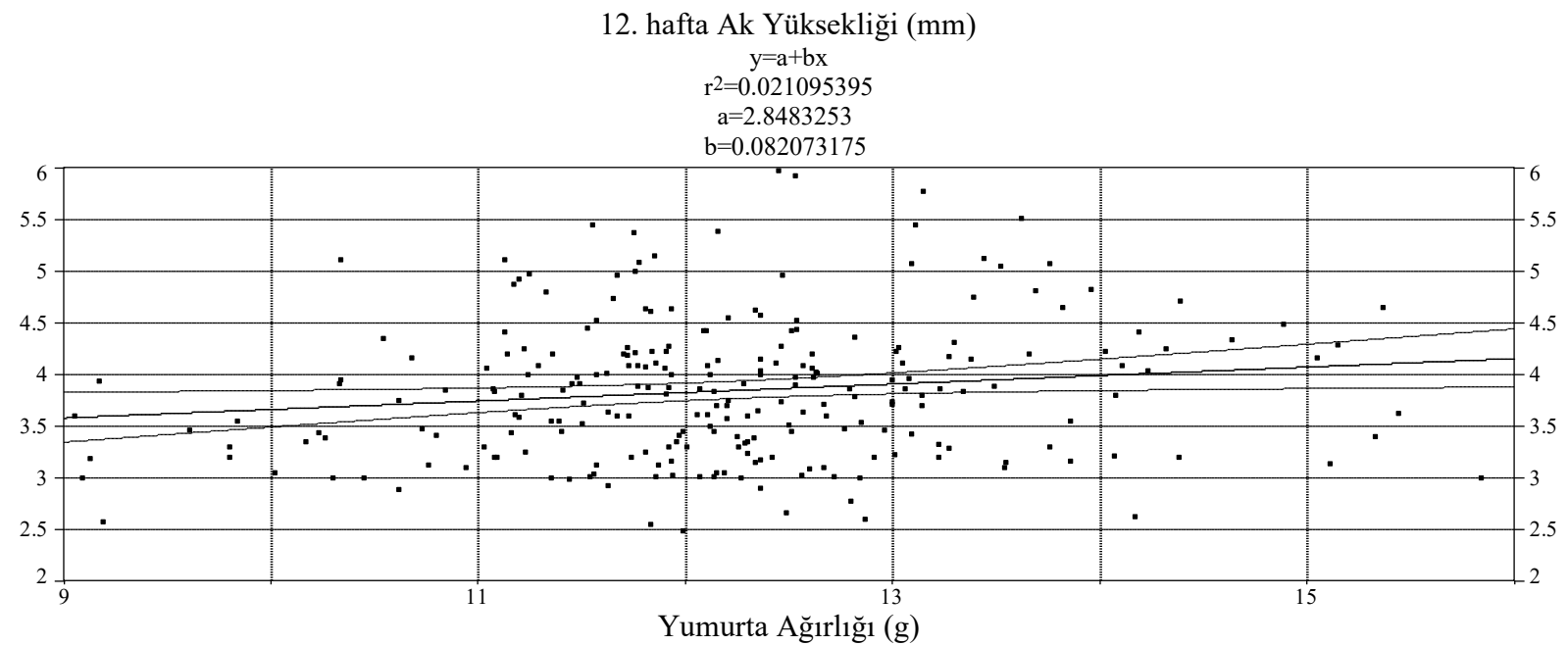

Şekil 2. On iki haftalık yaşta koyu ak yüksekliği ile yumurta ağırlığı arasındaki regresyon eğrisi Figure 2. Linear regression curve of thick albumen height on egg weight at twelve weeks of age

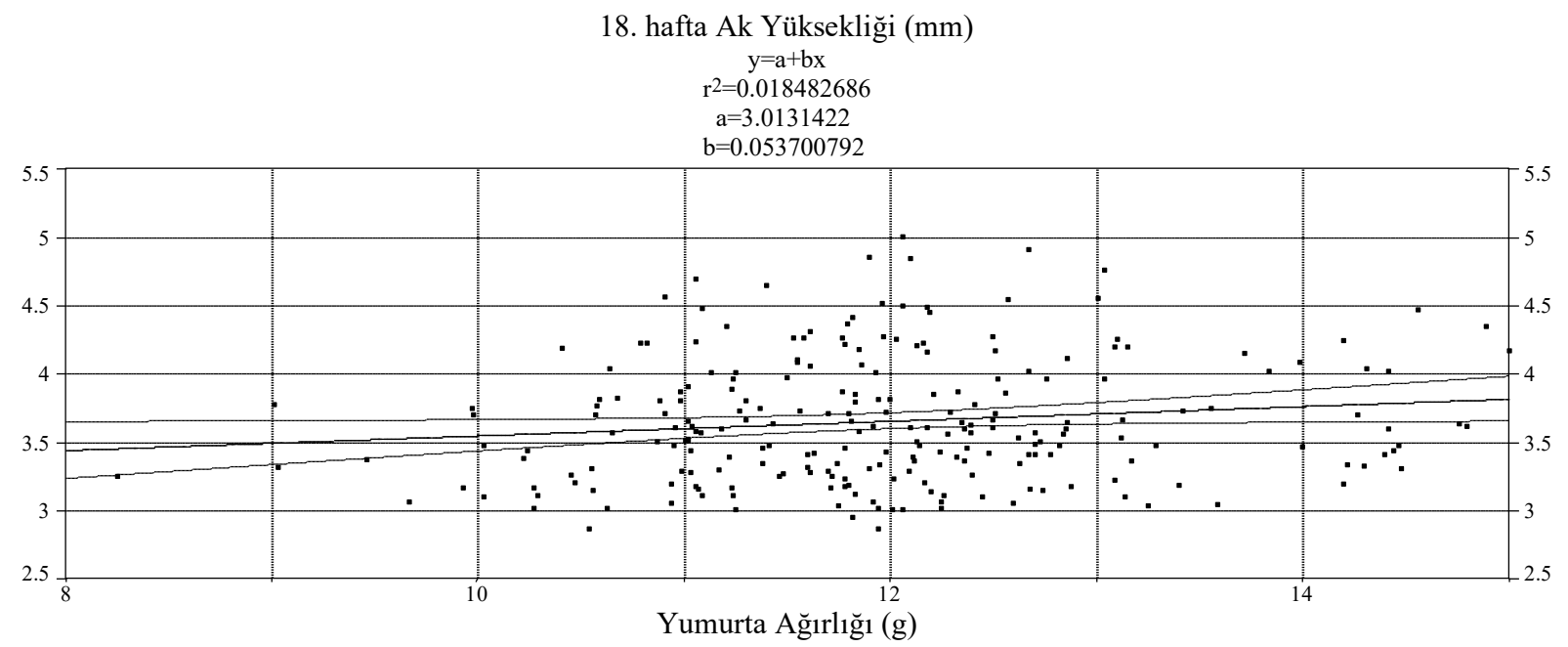

Şekil 3. On sekiz haftalık yaşta koyu ak yüksekliği ile yumurta ağırlığı arasındaki regresyon eğrisi Figure 3. Linear regression curve of thick albumen height on egg weight at eighteen weeks of age 
25. hafta Ak Yüksekliği (mm)

$\mathrm{y}=\mathrm{a}+\mathrm{bx}$

$\mathrm{r}^{2}=0.027613712$

$\mathrm{a}=2.7578625$

$\mathrm{b}=0.085543043$

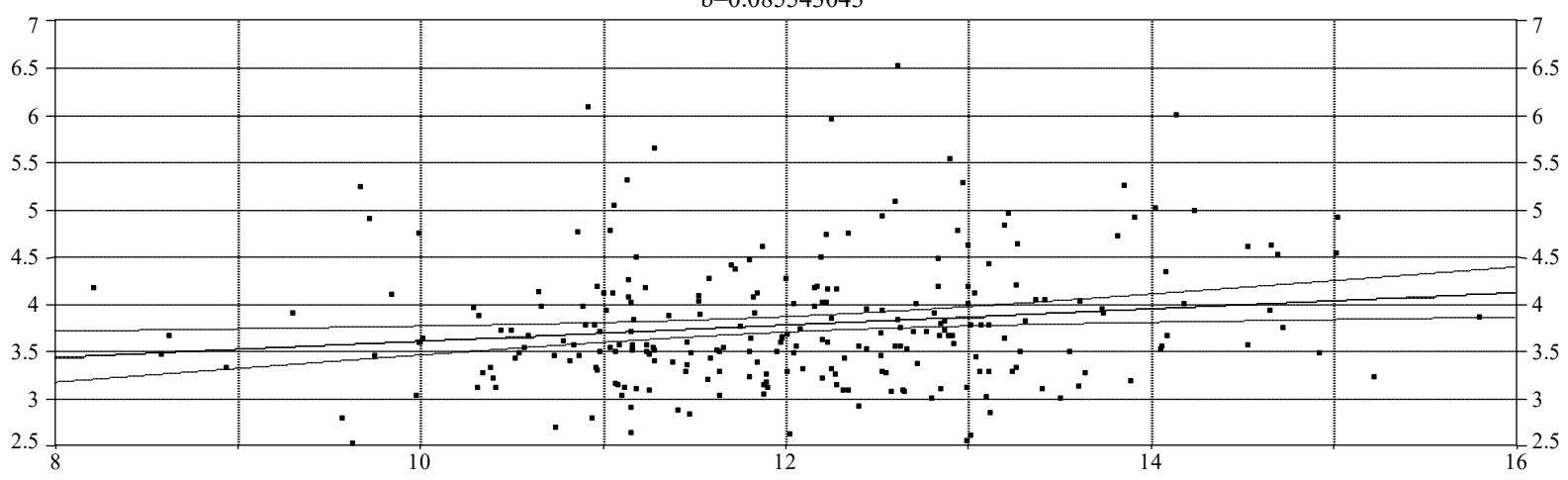

Yumurta Ağırlığı (g)

Şekil 4. Yirmi beş haftalık yaşta koyu ak yüksekliği ile yumurta ağırlığı arasındaki regresyon eğrisi Figure 4. Linear regression curve of thick albumen height on egg weight at twenty-five weeks of age

30. hafta Ak Yüksekliği (mm)

$$
\mathrm{y}=\mathrm{a}+\mathrm{bx}
$$

$r^{2}=0.024161909$

$\mathrm{a}=3.2169962$

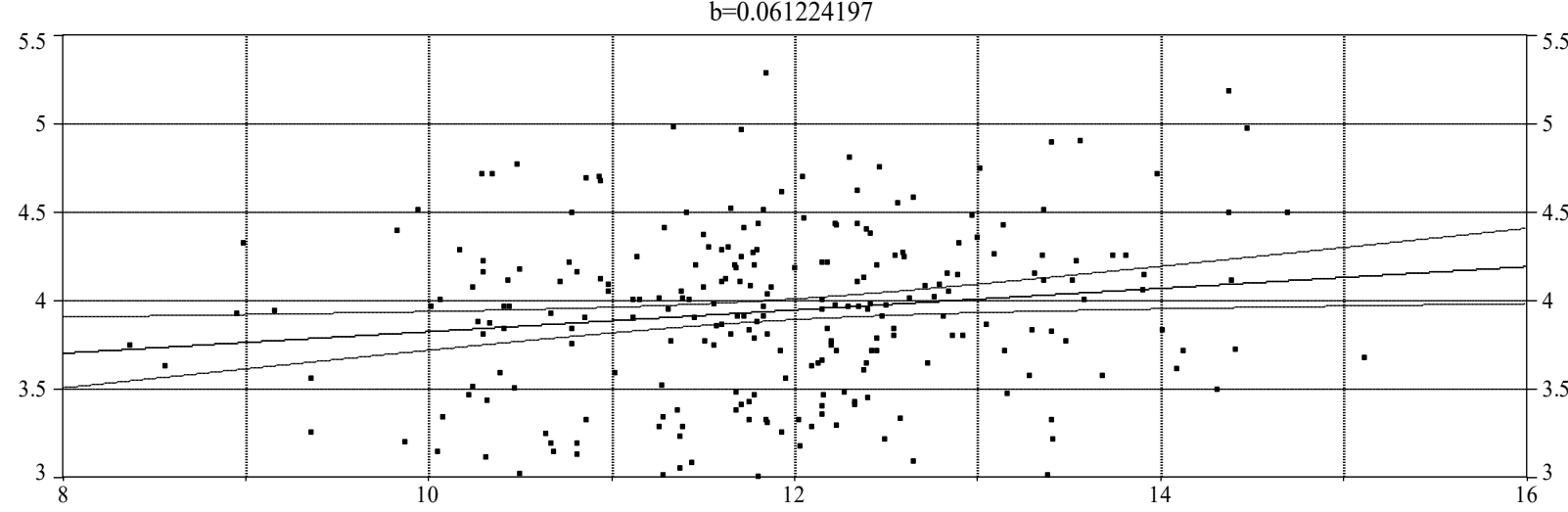

Yumurta Ağırlığı (g)

Şekil 5. Otuz haftalık yaşta koyu ak yüksekliği ile yumurta ağırlığı arasındaki regresyon eğrisi Figure 5. Linear regression curve of thick albumen height on egg weight at thirty weeks of age

4 gün depo Ak Yüksekliği (mm)

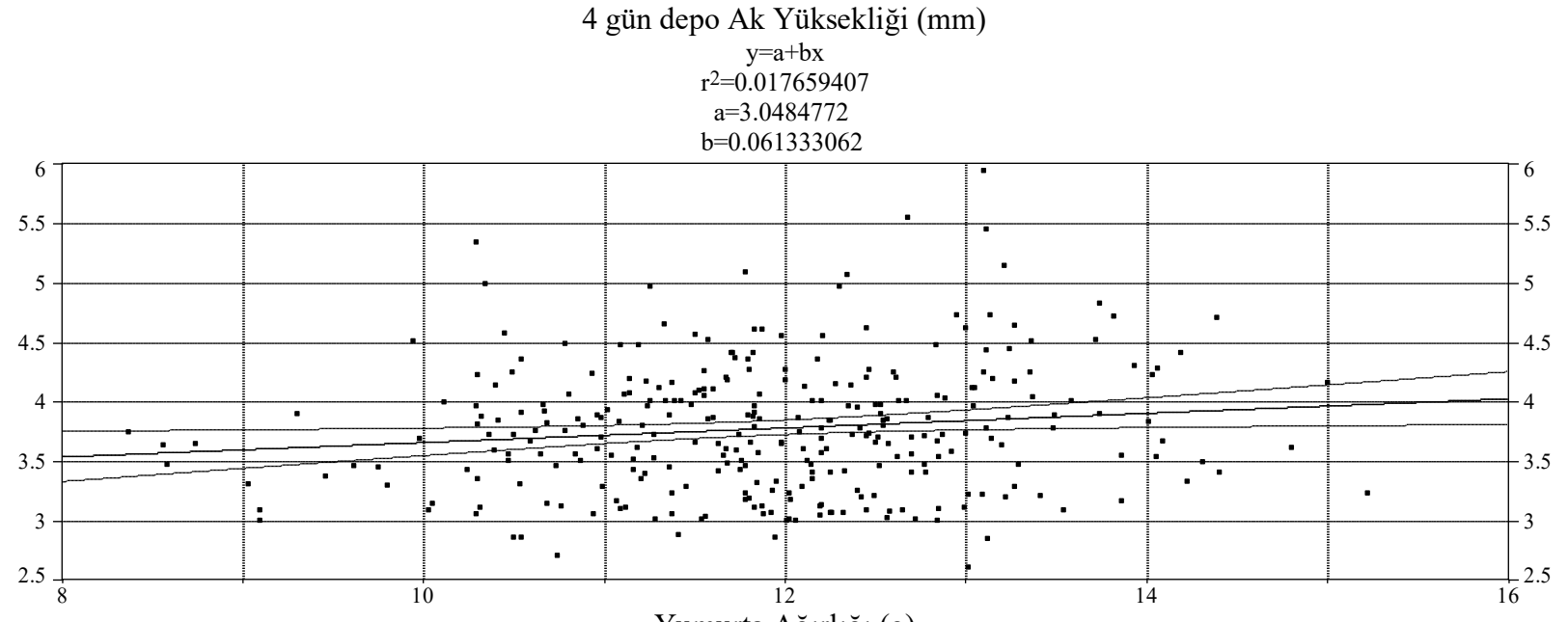

Yumurta Ağırlığı (g)

Şekil 6. Dört gün depolamada koyu ak yüksekliği ile yumurta ağırlığı arasındaki regresyon eğrisi

Figure 6. Linear regression curve of thick albumen height on egg weight at four-day storage 
Bildırcinlarda daha sonra yapilan benzer bir çalışmada, 10, 15 ve 20 haftalık yaştaki bıldırcınlarda ak yüksekliği ile yumurta ağırlığı arasındaki regresyon katsayıları sirasiyla 0,$115 ; 0,168$ ve $0,009 \mathrm{~mm} / \mathrm{g}, \mathrm{R}^{2}$ değerleri ise yine sirasıyla $\% 4,2 ; \% 5,5$ ve $\% 0,1$ olarak bildirilmiştir (Aktan, 2011a).

Ticari yumurtacı hibritlerden elde edilen yemeklik yumurtalar için koyu ak yüksekliğinin sürü yaşı üzerindeki regresyon katsayısının $-0,05 \mathrm{~mm} / \mathrm{g}$ şeklinde negatif değer aldığ 1 ve $\mathrm{R}^{2}$ değerinin de bu araştırmaya ait sonuçlardaki gibi düşük $(0,06)$ çıktığı bildirilmiştir (Silversides ve Budgell, 2004). Kuluçkalık yumurtaların depolanması durumunda sadece dört gün süreli depolamada koyu ak yüksekliği ile yumurta ağırlı̆̆ arasında 0,133 düzeyinde bir fenotipik korelasyon olduğu ve bunun istatistiki olarak önemli düzeyde olduğu belirlenmiştir. Buna göre dört gün süreli depolama için hazırlanan regresyon eğrisi Şekil 6'da verilmiştir. Şekil 6'da görüldügüü üzere dört gün süreli depolamada yumurta ağırlığ 1 g arttığında koyu ak yüksekliği de 0,061 mm artış göstermiştir. Yaş dönemlerinde olduğu gibi 4 gün süreli depolanan yumurtalarda da koyu ak yüksekliği bakımından gözlenen varyasyonun \%1,77 gibi çok düşük bir oranda yumurta ağırlığına bağlı olduğu saptanmıştır.

Yumurtacı ticari hibrit yumurtalarında belirlenen koyu ak yüksekliğinin depolama süresi üzerindeki regresyon katsayısı $-0,43 \mathrm{~mm}$ ile negatif ve daha yüksek bir değer aldığı, $\mathrm{R}^{2}$ değerinin ise daha yüksek $(0,41)$ bulunduğu bildirilmiştir (Silversides ve Budgell, 2004).

Araştırmacıların farklı bir kanatlı hayvan türünden elde edilen ve dölsüz yumurtalar kullandıkları göz önünde bulundurulduğunda karşılaştırma yapmak doğru olmayabilir. Aynı tür üzerinde çalışılmış olsa dahi döllü yumurtalarda koyu ak yüksekliğinin dölsüz yumurtalara göre daha düşük, koyu ak pH değerinin ise daha yüksek olduğu doğrultusunda bulgular vardır (Benton ve ark., 2001). Bulgularımızla paralel olarak, sadece 4 gün süreli depolanan bıldırcin yumurtalarında korelasyonun önemli bulunduğu, koyu ak yüksekliği ile yumurta ağırlığı arasındaki regresyon katsayısının $0,074 \mathrm{~mm} / \mathrm{g}$ olduğu, $\mathrm{R}^{2}$ değerinin ise \%12,2 olduğu araştırma sonuçları bulunmaktadır (Aktan, 2011a).

Kuluçkada inceleme konusu yapilan saatler açısından, kuluçkanın sadece sıfır ve altıncı saatlerinde koyu ak yüksekliği ile yumurta ve altıncı saatlerinde koyu ak yüksekliği ile yumurta ağırlığı arasında istatistiki olarak önemli düzeyde (sırasıyla 0,156 ve 0,174 ) fenotipik korelasyon belirlenmiş ve bu iki dönem için oluşturulan regresyon eğrileri sırasıyla Şekil 7 ve Şekil 8'de verilmiştir. Şekillerde de görüldüğü üzere kuluçkanın 0 ve 6 . saatlerinde yumurta ağırlıkları $1 \mathrm{~g}$ artış gösterdiğinde koyu ak yüksekliklerinin de sırasıyla 0,0808 ve $0,0809 \mathrm{~mm}$ arttığ 1 gözlenmiştir. Buna göre bu iki saat diliminde hesaplanan regresyon katsayılarının yaklaşık olarak aynı olduğu ve her iki saat diliminde de koyu ak yüksekliği bakımından gözlenen varyasyonun sirasıyla $\% 2,44$ ve \%3,03'lük k1smının yumurta ağırlığının farklı olmasindan kaynaklandığ görülmektedir.

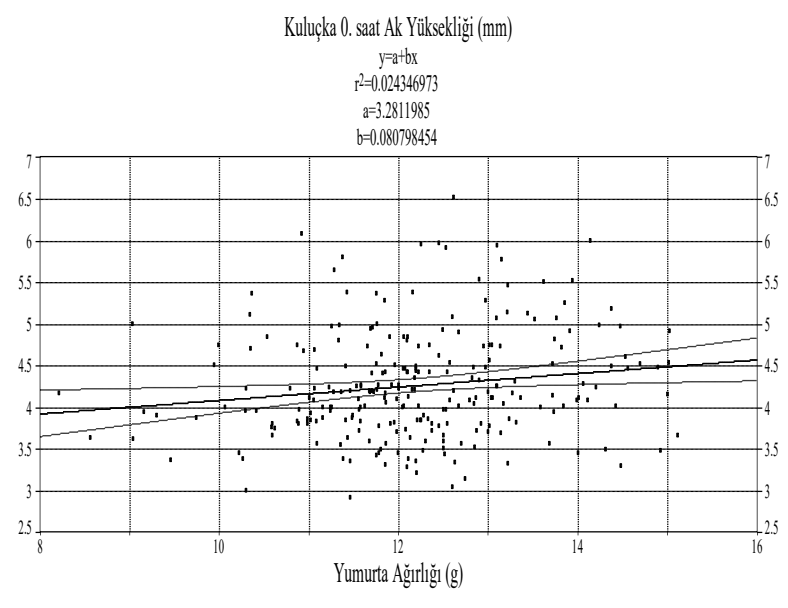

Şekil 7. Kuluçkanın 0. saatinde koyu ak yüksekliği ile yumurta ağırlığ 1 arasındaki regresyon eğrisi

Figure 7. Linear regression curve of thick albumen height on egg weight at 0 hour of incubation

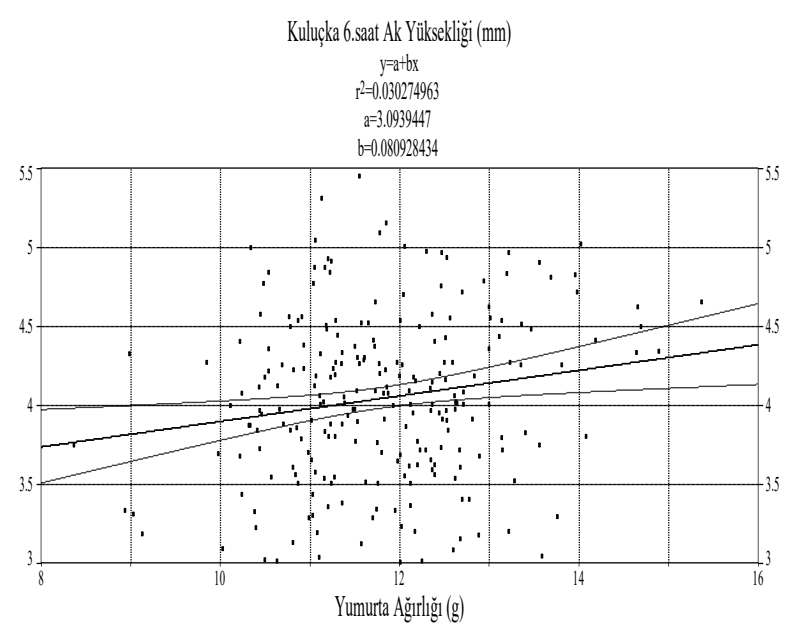

Şekil 8. Kuluçkanın 6.saatinde koyu ak yüksekliği ile yumurta ağırlığ 1 arasındaki regresyon eğrisi

Figure 8. Linear regression curve of thick albumen height on egg weight at 6 th hour of incubation

\section{Sonuç}

Japon bıldırcınlarında da diğer kanatlı türlerinde olduğu gibi ilerleyen yaşla birlikte koyu ak yüksekliği düşmektedir. Sıvılaşmanın matematiksel olarak tanımlanmasında viskozite ölçümü mümkün olsa da ak yüksekliğinin ölçülmesi ve yumurta ağırlığı ile ak yüksekliği arasında bilerek veya bilmeyerek sabit şekilde var olduğu farz edilen ilişkilerden yola çıkarak hesaplanan HU ve IQU gibi parametreler de yaygın olarak kullanılmaktadır. Ancak bazı araştırıcıların eleştirdiği ve araştırma sonuçlarının da desteklediği üzere, ak yüksekliği ile yumurta ağırlığı arasında sabit bir ilişki bulunmamaktadır. Bu nedenle de ak yüksekliğini yumurta ağırlığına göre düzelterek $H U$ ve IQU gibi değerler elde etmek ve karşılaştırma yapmak isabetli olmayacaktır. 


\section{Teşekkür}

$\mathrm{Bu}$ çalışma ilk yazarın yüksek lisans tezinden özetlenmiş olup, çalışmanın yapılabilmesi için alt yapı, hayvan materyali, yem vb. tüm olanakları sağlayan yeni adıyla Isparta Uygulamalı Bilimler Üniversitesi Ziraat Fakültesi Dekanlığına teşekkür ederiz.

\section{Kaynaklar}

Aktan, S., 2011a. Effects of age and storage duration on relationships among albumen quality traits and egg weight in Japanese quails. Journal of Animal and Veterinary Advances, 10(25): 3340-3344.

Aktan, S., 2011b. Effects of age and strain on relationships among albumen quality traits and egg weight in commercial brown layers. Journal of Animal and Veterinary Advances, 10(25): 3345-3349.

Alarslan, Ö.F., 2006. Modern Bildırcın Üretimi ve Temel Besleme Ilkeleri. 227 S., Ankara.

Anthon, M., Nau, F., Lechevalier, V., 2009. Egg proteins. (in Handbook of Hydrocolloids (2nd Ed.), Pages 359-382, ISBN 9781845694142, Woodhead Publishing.

Benton, C.E., Walsh, T.J., Brake, J., 2001. Effects of presence of a blastoderm on albumen height and $\mathrm{pH}$. Poultry Science, 80 : 955-957.

Eisen, E.J., Bohren, B.B., McKean, H.E., 1962. The Haugh unit as a measure of egg albumen quality. Poultry Science, 41: 1461-1468.

Haugh, R.R., 1937. The Haugh unit for measuring egg quality. US Egg Poultry Magazine, 43: 522-555, 572-573.

Hill, A.T., Hall, J.W., 1980. Effects of various combinations of oil spraying, washing, sanitizing, storage time, strain, and age upon albumen quality changes in storage and minimum sample sizes required for their measurement. Poultry Science, 59: 2237-2242.

Imai, C., 1986. Storage stability of quail (Coturnix coturnix japonica) eggs at room temperature. Poultry Science, 65: 474480.

Jacob, J.P., Miles, R.D. and Mather, F.B., 1998. Egg quality. Fact Sheet PS-24, 13 p., University of Florida, Cooperative Extension Service, Institute of Food and Agricultural Sciences.

Karabağ, K., Alkan, S., Balcıoğlu, S.M., 2010. The differences in some production and clutch traits in divergently selected Japanese quails. Kafkas Üniversitesi Veteriner Fakültesi Dergisi, 16(3): 383-387.

Kondaiah, N., Panda, B., Singhal, R.A., 1983. Internal egg quality measure for quail eggs. Indian Journal of Animal Science, 53(11): 1261-1264.

Koskan, O., Aktan, S., Kuru, N., 2016. Examination of Theil regression of nonparametric methods and linear regression analysis on Japanese quails having different sample size. Fresenius Environmental Bulletin, 25(9): 3673-3679.
Kul, S., Şeker, İ., 2004. Phenotypic correlations between some external and internal egg quality traits in the Japanese quail (Coturnix coturnix japonica). International Journal of Poultry Science, 3(6): 400-405.

Lechevalier, V., Croguennec, T., Anton, M., Nau, F., 2011. Processed egg products. (in Improving the Safety and Quality of Eggs and Egg Products: Egg Chemistry, Production and Consumption. Woodhead Publishing, Pages 538-581.

Nestor, K.E., Jaap, R.G., 1963. Egg weight may influence albumen height. Poultry Science, 42: 1249-1250.

Özçelik, M., 2002. The phenotypic correlations among some external and internal quality characteristics in Japanese quail eggs. Ankara Üniversitesi Veteriner Fakültesi Dergisi, 49: 67-72.

Papoulis, A., 1990. Probability and Statistics. Prentence-Hall International Editions, ISBN: 0137117302.

Scott, T.A., Silversides, F.G., 2000. The effect of storage and strain of hen on egg quality. Poultry Science, 79: 1725-1729.

Silversides, F.G., 1994. The Haugh unit correction for egg weight is not adequate for comparing eggs from chickens of different lines and ages. Journal of Applied Poultry Research, 3: 120-126.

Silversides, F.G., Budgell, K., 2004. The relationships among measures of egg albumen height, ph, and whipping volume. Poultry Science, 83: 1619-1623.

Silversides, F.G., Scott, T.A., 2001. Effect of storage and layer age on quality of eggs from two lines of hens. Poultry Science, 80: 1240-1245.

Silversides, F.G., Villeneuve, P., 1994. Is the Haugh unit correction for egg weight valid for eggs stored at room temperature? Poultry Science, 73: 50-55.

Toussant, M.J., Latshaw, J.D., 1999. Ovomucin content and composition in chicken eggs with different interior quality. Journal of the Science of Food and Agriculture, 79: 1666-1670.

Toussant, M.J., Swayne, D.E., Latshaw, J.D., 1995. Morphologic characteristics of oviducts from hens producing eggs of different haugh units induced by genetics and by feeding vanadium as determined with computer software- integrated digitizing technology. Poultry Science, 74: 1671-1676.

Uluocak, N., Okan, F., Efe, E., Nacar, H., 1995. B1ldırcın yumurtalarında bazı iç ve dış kalite özellikleri ile bunların yaşa göre değişimi. Turkish Journal of Veterinary and Animal Sciences, 19: 181-185.

Vogt, H. 1965. Untersuchungen über die Zusammensetzung von Ei und Fleisch bei der Japanischen Wachtel. Deutsche Geflügelwirtschaft, 17(19): 320-321.

Williams, K.C., 1992. Some factors affecting albumen quality with particular reference to Haugh unit score. World"es Poultry Science Journal, 48: 5-16.

Zynudheen, A.A., Anandan, R., Nair, K.G.R., 2008. Effect of dietary supplementation of fermented fish silage on egg production in Japanese quail (Coturnix coromandelica). African Journal of Agricultural Research, 3(5): 379-383. 